\title{
Benefits of different postoperative treatments in patients undergoing knee arthroscopic debridement
}

This article was published in the following Dove Press journal:

Open Access Rheumatology: Research and Reviews

25 September 2017

Number of times this article has been viewed

\author{
Cesáreo Trueba Vasavilbaso' \\ Carlos David Rosas Bello' \\ Erla Medina López ${ }^{2}$ \\ Maria Pilar Coronel \\ Granado 3 \\ José Mario Navarrete \\ Álvarez' \\ Cesáreo Angel Trueba \\ Davalillo 4 \\ Félix Isaac Gil Orbezo ${ }^{5}$ \\ 'Orthopedics Department, Hospital \\ Español de México, Mexico DF, \\ ${ }^{2}$ Orthopedics Department, Hospital \\ Médica Sur, Mexico City, Mexico; \\ ${ }^{3}$ International Development, Tedec \\ Meiji Farma SA, Madrid, Spain; \\ ${ }^{4}$ Orthopedics University Master \\ (National University of Mexico, \\ UNAM), ${ }^{5}$ Orthopedics Department, \\ Hospital Español de México, Mexico \\ City, Mexico
}

Purpose: To assess the effectiveness of viscosupplementation or platelet-rich plasma (PRP), compared to standard care, for pain relief after knee arthroscopic debridement in patients with meniscal pathology and osteoarthritis (OA), under normal clinical practice conditions.

Patients and methods: We conducted a prospective, randomized, evaluator-blind, pilot study. After arthroscopy, patients were randomized to receive 1) five injections of HA1 (Suprahyal ${ }^{\mathbb{} /}$ Adant $\left.^{\circledR}\right)$; 2) four injections of HA2 (Orthovisc $\left.{ }^{\circledR}\right)$; 3) three injections of HA3 $\left(\right.$ Synvisc $\left.^{\circledR}\right)$; 4) a single injection of PRP (GPSTM II); or 5) standard care (control). Patients were followed up for 18 months. Clinical outcomes were evaluated using the Western Ontario and McMaster Universities Arthritis Index (WOMAC) at 3, 6, 12, and 18 months. Minimally Clinical Important Improvement (MCII), as relative improvement $\geq 20$ for pain and function, was also calculated. Results: Fifty patients were included. At early follow-up ( 3 months), total WOMAC scores improved in all groups compared to baseline with reductions of $44.79 \%$ (HA1), $24.02 \%$ (HA2), $40.38 \%$ (HA3), $39.77 \%$ (PRP), and $27.64 \%$ (control) ( $p=0.002$ HA1 compared to HA2). At 18 months, the higher improvement in total WOMAC was in HA1 with a $65.20 \%$ reduction, followed by PRP (55.01\%), HA3 (49.57\%), and HA2 (29.82\%), whereas the control group had a $14.55 \%$ increase over baseline ( $p=0.001$ control compared to HA1 and HA3). The percentage of patients achieving the MCII for both pain and function at 18 months was $100 \%$ (HA1), 80\% (HA3), 60\% (HA2), and $60 \%$ (PRP), whereas, in the control group, all patients returned to pre-arthroscopy levels. There were no adverse events attributable to surgery or to intraarticular administration. Conclusion: Viscosupplementation following arthroscopy is more effective than PRP in adequately selected patients with meniscal lesions occurring concomitantly with OA. Further controlled studies with a larger sample size and/or alternative regimens would be of interest for the scientific community.

Keywords: arthroscopy, osteoarthritis, viscosupplementation, PRP

\section{Introduction}

Osteoarthritis (OA) is the most common of all joint diseases and exacts a heavy economic toll due to its high prevalence in the general population and potential for causing progressive disability. ${ }^{1}$ The etiology is multifactorial, including a variety of risk factors (aging, genetics, trauma, malalignment, and obesity) that interact to cause this disorder. ${ }^{2}$ The primary goal of treatment is the alleviation of pain, leading to an improvement in joint function and quality of life. Treatment options for knee OA include conservative measures, pharmacological treatments, intraarticular (IA) injections, and surgical intervention. ${ }^{3}$

\footnotetext{
Correspondence: Cesáreo Trueba Vasavilbaso

Orthopedics Department, Hospital Español de México, Avenida Ejército Nacional 617-cons 602, Colonia Granada, Delegación Miguel Hidalgo, Mexico City, Mexico

Tel +525552504002

Email cesareotv@yahoo.com
} 
Viscosupplementation is a well-established treatment option in OA. Hyaluronic acid (HA) exerts a mechanical effect providing lubrication of the joint, protecting against loads and impacts, and restoring the rheological properties of the synovial fluid. ${ }^{4} \mathrm{HA}$ also has a pharmacological effect by interacting with mediators of inflammation, inhibiting nociceptors of pain, stimulating chondrocyte growth, synthesis of extracellular matrix protein, and reduction of apoptosis in osteoarthritic cartilage..$^{5-8}$ HA products that are available differ in many characteristics, including origin (animal vs biofermentation), molecular weight (MW), structure (linear, crosslinked, and mix of both), volume of injection, and posology. Clinical investigations with these products have been mainly focused on the potential differences attributable to MW. Arbitrarily, different HA products have been divided into three MW categories: low (500-730 kDa), intermediate (800-2,000 kDa), and high MW (2,000-6,000 kDa) including crosslinked formulations of HA. ${ }^{9}$

The therapeutic use of platelet-rich plasma (PRP) is based on the use of the patient's own platelets as carrier of growth factors and other proteins (eg, fibronectin and other adhesive proteins) that play an important role in cell biology. The resulting products vary in their leukocyte content, platelet concentration, subsequent activation, and, at this moment, it is not defined what should be the ideal concentration of platelets that should reach the preparations as well as the dosage regimen. ${ }^{10}$ Although it seems PRP may improve the symptomatology, one part of the scientific community considers that there still exists a lack of clarity in available evidence for this to be recommended in international guidelines. ${ }^{11}$

Knee arthroscopy has become the gold standard in the diagnosis of meniscal and ligamentous injury ${ }^{12}$ and also plays a role in their management. ${ }^{13}$ This intervention has been widely used as a treatment for OA of the knee, but recent studies ${ }^{14-16}$ with controversial design and methodology $^{17}$ have questioned its usefulness. However, it should be noted that $>90 \%$ of patients with symptomatic knee OA have magnetic resonance imaging findings compatible with meniscal pathology. ${ }^{18}$ Therefore, arthroscopic surgery would be indicated in those patients with meniscal injuries, loose bodies, osteochondral lesions, or synovial pathology, with a concomitant diagnosis of knee OA playing an essential role in the adequate selection of patients who can benefit from this technique. ${ }^{19}$

Arthroscopy has decreased morbidity as compared with that in open procedures, but it has not eliminated pain completely. The causative factors behind this persistent pain are unknown, although it is known that most of the IA structures of the knee, including the synovial tissue, the anterior fat pad, and the joint capsule, have free nerve endings that are capable of sensing painful stimuli and producing severe pain. ${ }^{20,21}$ Moreover, it has been postulated that the severity and extent of OA, the degree of debridement undertaken, and the skill of the surgeon could be factors involved. ${ }^{22}$

Considering the abovementioned aspects, this study was planned as a pilot to assess the effectiveness of different treatments such as viscosupplementation or PRP as compared to standard care for pain relief after knee arthroscopic debridement in patients with meniscal pathology and OA, under normal clinical practice conditions.

\section{Patients and methods}

\section{Ethics}

The study was conducted in accordance with the Good Clinical Practice guidelines and in compliance with the principles of the Declaration of Helsinki. The study protocol was approved by the local Ethics Review Board from Hospital Español de México, and all patients gave written informed consent to participate in the study.

\section{Design}

This was a prospective, randomized, evaluator-blind, pilot study with four parallel arms and a control group.

Eligible patients were informed about study purpose and design. Demographic characteristics and medical history of the participants were recorded, and laboratory tests were done. X-rays of both knees were performed using anteroposterior projection with support, lateral with $30^{\circ}$ flexion, and Merchant $\left(45^{\circ}\right)$ views; bipodalic mechanical axis digitalization as well as magnetic resonance imaging of the affected knee were also done.

Arthroscopies were all carried out by a single orthopedic/ arthroscopic surgeon. All patients were given three doses of antibiotic (cephalothin $1 \mathrm{~g}$ ) as prophylaxis. Postsurgical pain treatment comprised oral acetaminophen $1 \mathrm{~g} / 8 \mathrm{~h}$ and celecoxib $200 \mathrm{mg} / 12 \mathrm{~h}$ for 10 days.

After surgery, patients were randomized to receive: 1) five IA injections of HA1 (Suprahyal ${ }^{\circledR} /$ Adant $^{\circledR}$ : biofermentation, non-crosslinked, $600-1,200 \mathrm{kDa}, 25 \mathrm{mg} /$ syringe); 2) four IA injections of HA2 (Orthovisc ${ }^{\circledR}$ : biofermentation, noncrosslinked, 1,700-2,900 kDa, $30 \mathrm{mg} /$ syringe); 3) three IA injections of HA3 (Synvisc ${ }^{\circledR}$ : chicken combs, crosslinked, 7,000 kDa, $16 \mathrm{mg} /$ syringe); 4) a single IA injection of PRP (GPS $\left.{ }^{\circledR} \mathrm{II}\right)$; and 5) standard care. The HAs used were considered of interest as they have different characteristics, ${ }^{23,24}$ to study whether these differences could have any impact on 
the efficacy/safety results. The number of doses specified are those authorized for each product. ${ }^{23}$

The GPS ${ }^{\circledR}$ II is a closed system that enables PRP to be collected while avoiding the risk of contamination and makes possible to concentrate the autologous platelets for reinjection locally. ${ }^{25}$

Eligible patients were randomized 1:1 using a computergenerated list of random numbers. The random sequence was created using freely accessible tools available at http://www. randomization.com, which uses the pseudo-random number generator of Wichmann and Hill, ${ }^{26}$ modified by McLeod. ${ }^{27}$

PRP was administered immediately after arthroscopy and viscosupplements were given once a week, starting at 21 days post-arthroscopy. Rescue medication comprised acetaminophen $1 \mathrm{~g} / 8 \mathrm{~h}$ and celecoxib $200 \mathrm{mg} / 12 \mathrm{~h}$.

The administration of IA treatments was conducted under aseptic conditions, inserting the needle into the patellofemoral joint space by a superolateral approach, with the patients in a supine position. In case effusion was present, it was removed before each injection.

Follow-up was conducted by five orthopedic surgeons, each one assigned to a specific group and blinded to the treatment administered. Visits were scheduled at 3, 6, 12, and 18 months after arthroscopy.

All patients were prescribed the same protocol of rehabilitation to be followed at the patient's convenience. The rehabilitation protocol started progressively, starting with isometric exercises and muscle stretching from Week 1 post-arthroscopy, adding weight exercises from Week 3, cardiovascular training from Week 7 , and high-impact exercises from 3 months onward.

\section{Patient selection criteria}

Eligible patients were men and women, aged 40-85, with body mass index (BMI) $<35 \mathrm{~kg} / \mathrm{m}^{2}$, and indications for knee arthroscopic surgery due to symptomatic meniscal rupture Mink et $\mathrm{al}^{28}$ grade III confirmed by magnetic resonance imaging, radiographic OA grades I-II according to Kellgren and Lawrence $(\mathrm{KL}),{ }^{29}$ meniscal preservation $>60 \%$, ligament integrity, and ability and willingness to provide informed consent for study participation.

Main exclusion criteria were infectious conditions, use of anticoagulants, history of trauma (dislocation or fracture), inflammatory arthritis, microcrystalline arthropathies, history of septic arthritis, ligament injury, nonspecific synovitis, angular deformity $>10^{\circ}$, chondral lesions G-IV Outerbridge $\left(>1 \mathrm{~cm}^{2}\right),{ }^{30}$ neoplasms, or allergy to any of the components of the products under study.

\section{Evaluation of efficacy}

Efficacy was evaluated using the Western Ontario McMaster University Osteoarthritis Index (WOMAC) total and subscales of pain, stiffness, and function using a five-point $(0-4)$ Likert scale. Scores at the end of follow-up (18 months) were compared to baseline and the differences between treatment groups were analyzed. Secondary outcomes were efficacy rates at the different follow-up visits.

The WOMAC questionnaire used was the Spanish translated version from Batlle-Gualda et al, ${ }^{31}$ validated by Escobar et al. ${ }^{32}$ The number of patients achieving the Minimal Clinically Important Improvement (MCII) in each treatment group was also calculated. The MCII is the smallest change in measurement that signifies an important improvement in a patient's symptom..$^{33}$ According to Tubach et al, ${ }^{34}$ a 15 out of 100 for absolute improvement and $20 \%$ for relative improvement could be used as cutoffs for MCII estimation. Taking into account that, in our study, a Likert scale was used, the $20 \%$ of relative improvement cutoff was applied. ${ }^{33}$

\section{Evaluation of safety}

The incidence and type of adverse events was recorded throughout the study.

\section{Statistics}

Categorical variables were summarized by their number and relative frequencies. For continuous variables following a normal distribution (Kolmogorov-Smirnov test), mean, standard deviation, and maximum and minimum values were used. Non-normally distributed variables were summarized with their median, interquartile range, minimum, and maximum.

Changes in WOMAC total and subscales at 3, 6, 12, and 18 months were expressed as raw scores and as percentage of change from the baseline value. Comparisons between groups were done using chi-square test or Fisher's Exact test for categorical variables when necessary. Continuous data were analyzed using Mann-Whitney test.

The study was designed as a pilot evaluation; therefore, real sample-size estimation was not done.

The main population for analysis was the per protocol (PP) population, comprising patients who completed the 18 months follow-up according to the study protocol. Safety analysis was conducted in all patients who received at least one IA injection.

Data were analyzed using SPSS V14 (SPSS Inc, Chicago Il). All tests were two-sided, and the statistical significance was set at 0.05 . 


\section{Results}

\section{Disposition of patients and demographics}

Patients were recruited from March 2013 to October 2014.

Ninety patients were initially screened, of whom 40 were excluded due to age $(n=4)$, history of trauma or ligament involvement $(n=5)$, overweight $(n=6)$, meniscal injury > $40 \%(\mathrm{n}=4)$, chondral lesions G-IV (Outerbridge $>1 \mathrm{~cm}^{2}$; $\mathrm{n}=5$ ), eventual total knee arthroplasty (TKA) $(\mathrm{n}=7)$, lost to follow-up $(n=8)$, or death unrelated to the study $(n=1)$, leaving a total of 50 patients who participated in the study and completed all procedures as scheduled (Figure 1).

Among study subjects, $52 \%$ were male and the mean age was 64.4 years, with statistically significant differences between HA2 and HA3 ( $p=0.007)$. Mean BMI was $27.8 \mathrm{~kg} /$ $\mathrm{m}^{2}$ without differences among groups $(p=0.693)$, despite HA2 comprising more obese patients (Table 1).

Near all patients in the HA3 group had mild OA (KL grade I), with the differences significant versus HA2 $(p=0.001)$ and control $(p=0.002)$. The groups were homogeneous with respect to WOMAC total values $(p=0.062)$ as well as pain $(p=0.234)$, stiffness $(p=0.383)$, and function ( $p=0.089)$ subscales (Table 1).
There were no differences among groups in arthroscopic lesions (Table 2). The following surgical procedures were conducted: partial meniscectomy of no more than $40 \%$ (35 patients), synovectomy and resection of Hoffa's fat pad (five patients), and debridement and stabilization of the chondral lesion (16 patients). More than one procedure in the same patient was possible.

\section{Efficacy}

At early follow-up (3 months), total WOMAC scores improved as compared to baseline, in all groups with reductions of $44.79 \%$ (HA1), $24.0 \%$ (HA2), $40.38 \%$ (HA3), $39.77 \%$ (PRP), and $27.64 \%$ (control), ( $p=0.002 \mathrm{HAl}$ compared to HA2).

At 18 months, a higher improvement in total WOMAC was observed in HA1 with a $65.20 \%$ reduction, followed by PRP (55.01\%), HA3 (49.57\%), and HA2 (29.82\%), whereas the control group had a $14.5 \%$ increase over baseline despite the use of rescue medication and rehabilitation, with the differences statistically significant with respect to HA1 and HA3 ( $p=0.001$; Table 3 and Figures 2A-D).

At 3 months follow-up, the percentage of patients achieving the MCII for both pain and function (20\% of relative

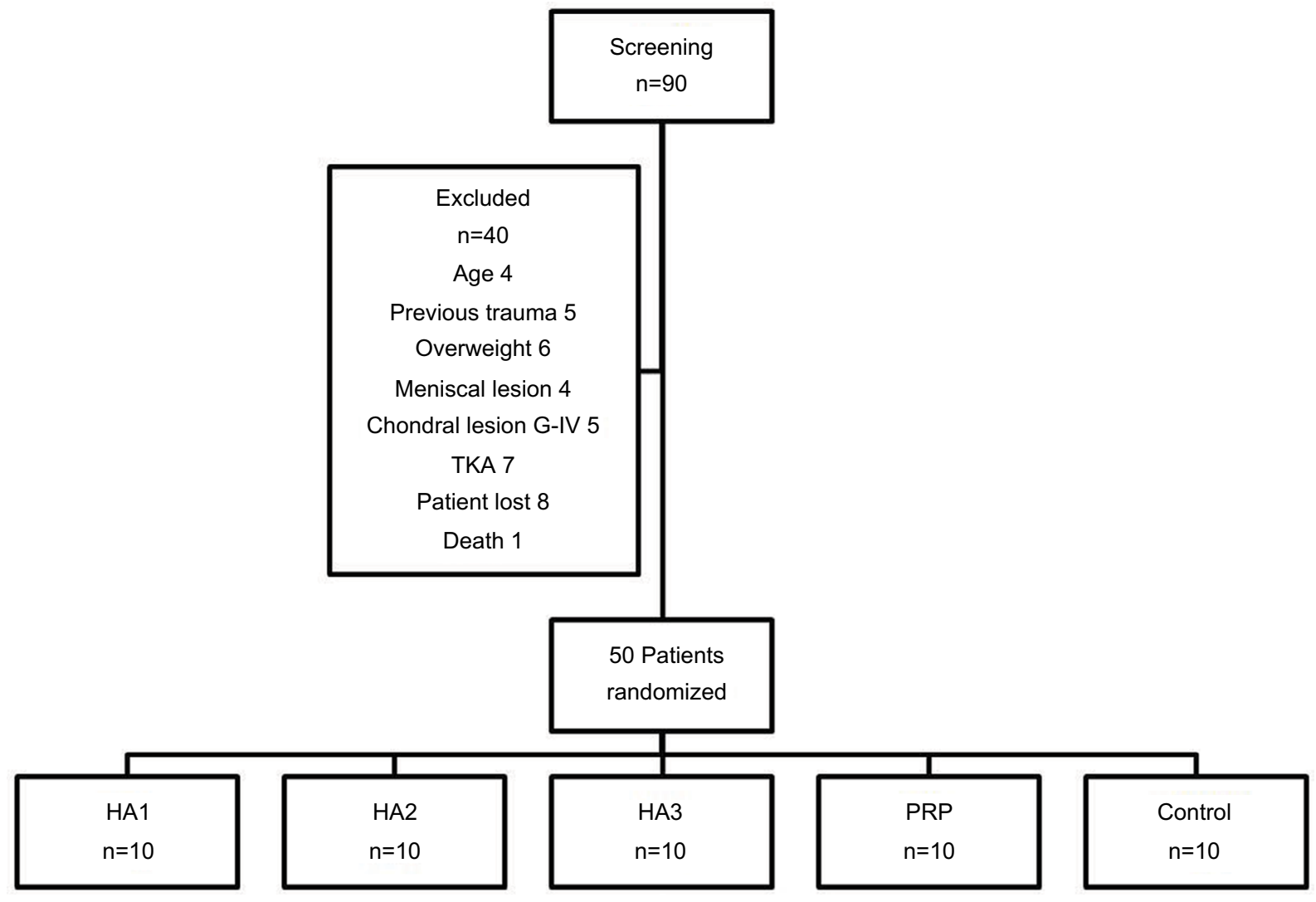

Figure I Disposition of patients.

Abbreviations: PRP, platelet-rich plasma; TKA, total knee arthroplasty. 
Table I Demographics and baseline condition of study groups

\begin{tabular}{|c|c|c|c|c|c|c|c|}
\hline & $\begin{array}{l}\text { HAI } \\
(n=\mid 0)\end{array}$ & $\begin{array}{l}\text { HA2 } \\
(n=10)\end{array}$ & $\begin{array}{l}\text { HA3 } \\
(n=10)\end{array}$ & $\begin{array}{l}\text { PRP } \\
(n=10)\end{array}$ & $\begin{array}{l}\text { Control } \\
(n=10)\end{array}$ & $\begin{array}{l}\text { Total } \\
(n=50)\end{array}$ & $p$ \\
\hline Sex M, n (\%) & $\begin{array}{l}7 \\
(70.0)\end{array}$ & $\begin{array}{l}4 \\
(40.0)\end{array}$ & $\begin{array}{l}6 \\
(60.0)\end{array}$ & $\begin{array}{l}4 \\
(40.0)\end{array}$ & $\begin{array}{l}5 \\
(50.0)\end{array}$ & $26(52.0)$ & ns \\
\hline Age, mean (SD) & $\begin{array}{l}66.3 \\
(9.6)\end{array}$ & $\begin{array}{l}71.1 \\
(7.0)\end{array}$ & $\begin{array}{l}56.9 \\
(9.8)\end{array}$ & $\begin{array}{l}60.3 \\
(9.5)\end{array}$ & $\begin{array}{l}67.5 \\
(7.8)\end{array}$ & $\begin{array}{l}64.4 \\
(9.9)\end{array}$ & $\begin{array}{l}\text { HA2 vs HA3 } \\
p=0.007\end{array}$ \\
\hline Age distribution & & & & & & & \\
\hline$\leq 65$ & 5 & 1 & 7 & 6 & 4 & $23(46 \%)$ & \\
\hline$>65$ & 5 & 9 & 3 & 4 & 6 & 27 (54\%) & \\
\hline BMI, mean (SD) & $\begin{array}{l}26.6 \\
(3.2)\end{array}$ & $\begin{array}{l}28.9 \\
(3.0)\end{array}$ & $\begin{array}{l}27.6 \\
(2.8)\end{array}$ & $\begin{array}{l}28.0 \\
(3.6)\end{array}$ & $\begin{array}{l}28.1 \\
(3.2)\end{array}$ & $27.8(3.1)$ & ns \\
\hline BMI distribution & & & & & & & \\
\hline$\leq 24.9$ & 3 & I & I & I & I & 7 (14\%) & \\
\hline$\geq 25->29.9$ & 5 & 3 & 6 & 6 & 5 & $25(50 \%)$ & \\
\hline$\geq 30->34.9$ & 2 & 6 & 3 & 3 & 4 & $18(36 \%)$ & \\
\hline Grade II K\&L (\%) & $\begin{array}{l}6 \\
(60.0)\end{array}$ & $\begin{array}{l}10 \\
(100.0)\end{array}$ & $\begin{array}{l}2 \\
(20.0)\end{array}$ & $\begin{array}{l}6 \\
(60.0)\end{array}$ & $\begin{array}{l}9 \\
(90.0)\end{array}$ & $33(66.0)$ & $\begin{array}{l}\text { HA2 vs } H A 3 \\
p=0.00 \mathrm{I} \\
\text { HA3 vs Control } p=0.002\end{array}$ \\
\hline WOMAC, mean ( & & & & & & & \\
\hline Total & $\begin{array}{l}52.40 \\
(20.40)\end{array}$ & $\begin{array}{l}67.00 \\
(4.42)\end{array}$ & $\begin{array}{l}56.60 \\
(17.58)\end{array}$ & $\begin{array}{l}54.80 \\
(11.26)\end{array}$ & $\begin{array}{l}65.10 \\
(12.73)\end{array}$ & - & ns \\
\hline Pain & $\begin{array}{l}14.30 \\
(4.11)\end{array}$ & $\begin{array}{l}\text { I5.80 } \\
(3.05)\end{array}$ & $\begin{array}{l}15.50 \\
(1.90)\end{array}$ & $\begin{array}{l}13.40 \\
(3.03)\end{array}$ & $\begin{array}{l}13.00 \\
(4.24)\end{array}$ & - & ns \\
\hline Stiffness & $\begin{array}{l}5.30 \\
(1.89)\end{array}$ & $\begin{array}{l}3.80 \\
(1.93)\end{array}$ & $\begin{array}{l}5.30 \\
(1.89)\end{array}$ & $\begin{array}{l}5.00 \\
(2.16)\end{array}$ & $\begin{array}{l}5.10 \\
(2.28)\end{array}$ & - & ns \\
\hline Function & $\begin{array}{l}32.80 \\
(18.96)\end{array}$ & $\begin{array}{l}47.40 \\
(6,56)\end{array}$ & $\begin{array}{l}32.90 \\
(17.57)\end{array}$ & $\begin{array}{l}36.40 \\
(13.16)\end{array}$ & $\begin{array}{l}49.20 \\
(12.34)\end{array}$ & - & ns \\
\hline
\end{tabular}

Abbreviations: PRP, platelet-rich plasma; WOMAC, Western Ontario and McMaster Universities Arthritis Index.

Table 2 Type of lesion

\begin{tabular}{|c|c|c|c|c|c|c|c|}
\hline Localization, n (\%) & $\begin{array}{l}\text { HAI } \\
(n=10)\end{array}$ & $\begin{array}{l}\text { HA2 } \\
(n=10)\end{array}$ & $\begin{array}{l}\text { HA3 } \\
(n=10)\end{array}$ & $\begin{array}{l}\text { PRP } \\
(n=10)\end{array}$ & $\begin{array}{l}\text { Control } \\
(n=10)\end{array}$ & $p$-value & $\begin{array}{l}\text { Total } \\
(n=50)\end{array}$ \\
\hline Lateral meniscus & $\begin{array}{l}2 \\
(20.0)\end{array}$ & $\begin{array}{l}4 \\
(40.0)\end{array}$ & $\begin{array}{l}4 \\
(40.0)\end{array}$ & $\begin{array}{l}2 \\
(20.0)\end{array}$ & $\begin{array}{l}3 \\
(30.0)\end{array}$ & ns & $\begin{array}{l}15 \\
(30.0)\end{array}$ \\
\hline Medial meniscus & $\begin{array}{l}6 \\
(60.0)\end{array}$ & $\begin{array}{l}6 \\
(60.0)\end{array}$ & $\begin{array}{l}5 \\
(50.0)\end{array}$ & $\begin{array}{l}2 \\
(20.0)\end{array}$ & $\begin{array}{l}4 \\
(40.0)\end{array}$ & ns & $\begin{array}{l}23 \\
(46.0)\end{array}$ \\
\hline Synovitis & $\begin{array}{l}10 \\
(100)\end{array}$ & $\begin{array}{l}7 \\
(70.0)\end{array}$ & $\begin{array}{l}8 \\
(80.0)\end{array}$ & $\begin{array}{l}10 \\
(100)\end{array}$ & $\begin{array}{l}9 \\
(90.0)\end{array}$ & ns & $\begin{array}{l}44 \\
(88.0)\end{array}$ \\
\hline Hoffitis & $\begin{array}{l}9 \\
(90.0)\end{array}$ & $\begin{array}{l}10 \\
(100)\end{array}$ & $\begin{array}{l}10 \\
(100)\end{array}$ & $\begin{array}{l}8 \\
(80.0)\end{array}$ & $\begin{array}{l}8 \\
(80.0)\end{array}$ & ns & $\begin{array}{l}45 \\
(90.0)\end{array}$ \\
\hline Lateral condyle & $\begin{array}{l}\text { I } \\
(10.0)\end{array}$ & $\begin{array}{l}5 \\
(50.0)\end{array}$ & $\begin{array}{l}1 \\
(10.0)\end{array}$ & $\begin{array}{l}4 \\
(40.0)\end{array}$ & $\begin{array}{l}2 \\
(20.0)\end{array}$ & ns & $\begin{array}{l}13 \\
(26.0)\end{array}$ \\
\hline Patellofemoral & $\begin{array}{l}1 \\
(10.0)\end{array}$ & $\begin{array}{l}2 \\
(20.0)\end{array}$ & $\begin{array}{l}1 \\
(10.0)\end{array}$ & $\begin{array}{l}2 \\
(20.0)\end{array}$ & $\begin{array}{l}0 \\
(0.0)\end{array}$ & ns & $\begin{array}{l}6 \\
(12.0)\end{array}$ \\
\hline
\end{tabular}

Abbreviation: PRP, platelet-rich plasma.

Table 3 Evolution of total WOMAC expressed as raw data and relative change at follow-up visits in treatment groups.

\begin{tabular}{|c|c|c|c|c|c|c|c|c|c|c|c|}
\hline \multirow{2}{*}{$\begin{array}{l}\text { WOMAC } \\
\text { Total, mean } \\
\text { (SD) }\end{array}$} & \multicolumn{2}{|l|}{ HAI } & \multicolumn{2}{|l|}{ HA2 } & \multicolumn{2}{|l|}{ HA3 } & \multicolumn{2}{|l|}{ PRP } & \multicolumn{2}{|c|}{ Control } & \multirow[t]{2}{*}{$p$-value } \\
\hline & Score & $\begin{array}{l}\text { Relative } \\
\text { change }\end{array}$ & Score & $\begin{array}{l}\text { Relative } \\
\text { change }\end{array}$ & Score & $\begin{array}{l}\text { Relative } \\
\text { change }\end{array}$ & Score & $\begin{array}{l}\text { Relative } \\
\text { change }\end{array}$ & Score & $\begin{array}{l}\text { Relative } \\
\text { change }\end{array}$ & \\
\hline 3 months & $\begin{array}{l}29.80 \\
(13.45)\end{array}$ & $\begin{array}{l}-44.79 \\
(8.33)\end{array}$ & $\begin{array}{l}50.60 \\
(5.87)\end{array}$ & $\begin{array}{l}-24.02 \\
(I I .42)\end{array}$ & $\begin{array}{l}35.20 \\
(|3.9|)\end{array}$ & $\begin{array}{r}-40.38 \\
(13.29)\end{array}$ & $\begin{array}{l}34.20 \\
(24.28)\end{array}$ & $\begin{array}{l}-39.77 \\
(36.30)\end{array}$ & $\begin{array}{l}44.00 \\
(3.94)\end{array}$ & $\begin{array}{l}-27.64 \\
(28.00)\end{array}$ & $\mathrm{HAl}$ vs HA2: 0.002 \\
\hline 6 months & $\begin{array}{l}20.00 \\
(12.01)\end{array}$ & $\begin{array}{l}-65.23 \\
(10.37)\end{array}$ & $\begin{array}{l}52.40 \\
(7.32)\end{array}$ & $\begin{array}{l}-20.87 \\
(16.55)\end{array}$ & $\begin{array}{l}19.00 \\
(7.86)\end{array}$ & $\begin{array}{l}-66.28 \\
(11.30)\end{array}$ & $\begin{array}{l}30.40 \\
(29.74)\end{array}$ & $\begin{array}{l}-47.55 \\
(47.08)\end{array}$ & $\begin{array}{l}37.00 \\
(11.90)\end{array}$ & $\begin{array}{l}-36.12 \\
(44.09)\end{array}$ & $\begin{array}{l}\text { HAI vs HA2: } 0.001 \\
\text { HA3 vs HA2: } 0.001\end{array}$ \\
\hline 12 months & $\begin{array}{l}17.20 \\
(13.07)\end{array}$ & $\begin{array}{l}-71.79 \\
(14.91)\end{array}$ & $\begin{array}{l}51.40 \\
(27.46)\end{array}$ & $\begin{array}{l}-21.44 \\
(45.94)\end{array}$ & $\begin{array}{l}18.60 \\
(8.55)\end{array}$ & $\begin{array}{l}-67.12 \\
(12.82)\end{array}$ & $\begin{array}{l}30.00 \\
(35.1 I)\end{array}$ & $\begin{array}{l}-48.84 \\
58.11\end{array}$ & $\begin{array}{l}53.50 \\
(16.50)\end{array}$ & $\begin{array}{l}-10.28 \\
50.08\end{array}$ & $\begin{array}{l}\text { HAI vs Control: } 0.00 \text { I } \\
\text { HA3 vs Control: } 0.00 \text { I }\end{array}$ \\
\hline 18 months & $\begin{array}{l}17.60 \\
(7.23)\end{array}$ & $\begin{array}{l}-65.20 \\
(8.89)\end{array}$ & $\begin{array}{l}46.30 \\
(25.88)\end{array}$ & $\begin{array}{l}-29.82 \\
(41.74)\end{array}$ & $\begin{array}{l}25.00 \\
(3.33)\end{array}$ & $\begin{array}{l}-49.57 \\
(22.72)\end{array}$ & $\begin{array}{l}27.00 \\
(36.75)\end{array}$ & $\begin{array}{l}-55.01 \\
(58.85)\end{array}$ & $\begin{array}{l}70.50 \\
(4.37)\end{array}$ & $\begin{array}{l}14.55 \\
(36.45)\end{array}$ & $\begin{array}{l}\text { HAI vs Control: } 0.00 \text { I } \\
\text { HA3 vs Control: } 0.001\end{array}$ \\
\hline
\end{tabular}

Abbreviations: PRP, platelet-rich plasma; WOMAC, Western Ontario and McMaster Universities Arthritis Index. 
A

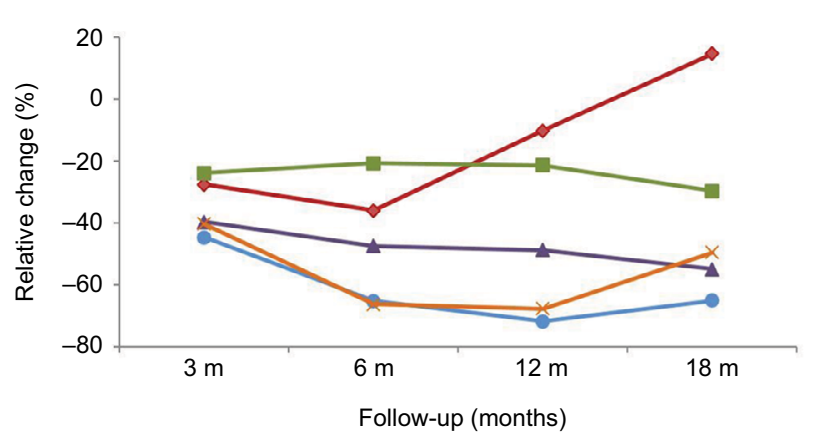

C

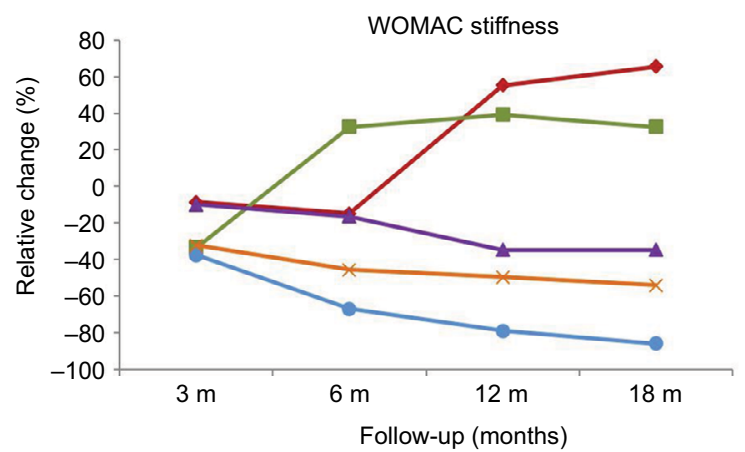

B

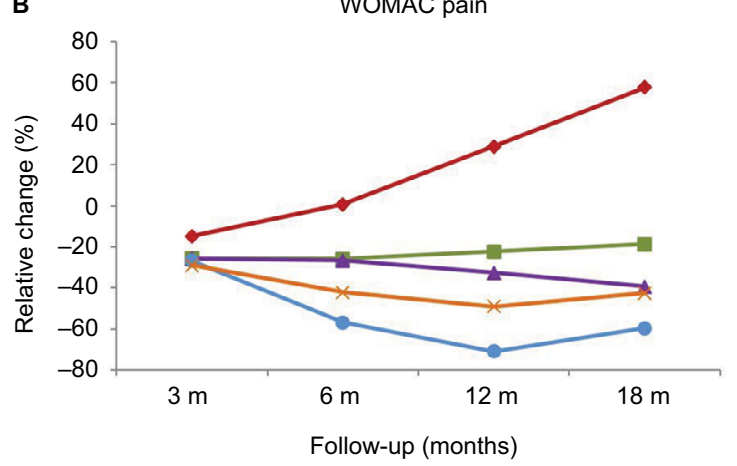

D

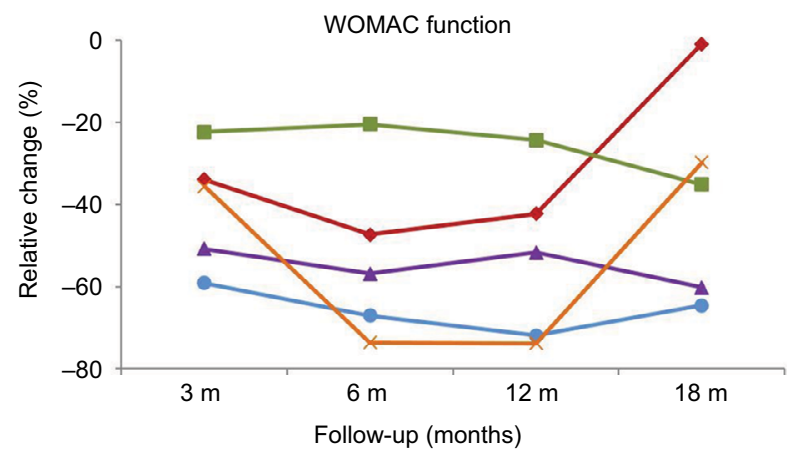

Figure 2 Evolution of relative change (\%) during the study vs baseline. $\bullet \mathrm{HAI}$; $\mathrm{HA} 2 ; \mathrm{X} \mathrm{HA3} ; \boldsymbol{\Delta R P} \bullet \mathrm{Control}$

WOMAC Total (A), $p$ values: 3 months: HAI vs HA2=0.002; 6 months: HAI vs HA2=0.00I; HA2 vs HA3=0.00I; 12 months: HAI vs Control=0.03I; HA3 vs Control= 0.046; and 18 months: HAI vs Control=0.00I; HA3 vs Control=0.003. WOMAC Pain (B), $p$ values: 3 months: NS differences; 6 months: HAI vs Control=0.026; HAI vs $\mathrm{HA} 2=0.002$; 12 months: $\mathrm{HAl}$ vs Control=0.012; $\mathrm{HAl}$ vs $\mathrm{HA} 2=0.008$; $\mathrm{HA} 3$ vs Control=0.004; and 18 months: $\mathrm{HAl}$ vs Control=0.00I; $\mathrm{HA} 2$ vs Control=0.030; $\mathrm{HA} 3$ vs Control=0.003. WOMAC stiffness (C), p values: 3 months: HAI vs Control: $0.00 \mathrm{I}$; HA3 vs Control: 0.038 ; 6 months: HAI vs Control: 0.003 ; 12 months: HAI vs Control: 0.001 ; HA3 vs Control: 0.010; and 18 months: HAI vs Control: 0.002 . WOMAC Function (D), $p$ values: 3 months: HAI vs HA2: 0.006 ; 6 months: HAI vs HA2=0.002; HA3 vs $\mathrm{HA} 2=0.00 \mathrm{I}$; 12 months: $\mathrm{HAI}$ vs Control=0.050: $\mathrm{HA} 3$ vs Control=0.049; and 18 months: HAI vs Control=0.002.

Abbreviations: PRP, platelet-rich plasma; WOMAC, Western Ontario and McMaster Universities Arthritis Index.

change) in different groups was $80 \%$ (HA1), 20\% (HA2), $40 \%$ (HA3), $30 \%$ PRP, and 30\% (control). At the end of follow-up, a growing number of patients experienced a clinically significant improvement in HA1 with a $100 \%$ responders rate, followed by HA3 (80\%). In the group treated with HA2 and in those treated with PRP, the results reached $60 \%$ responders, whereas in the control group, all patients returned to near pre-arthroscopy levels of pain and impairment and none of the patients reached the $20 \%$ MCII cutoff (Figure 3).

\section{Safety}

Throughout the overall study period, patients did not experience adverse events attributable to surgery or to IA injections.

\section{Discussion}

Arthroscopic surgery is frequently advocated as a treatment option to relieve symptoms of painful degenerative knee conditions. The rationale is that it may improve symptom and functions, has minimal morbidity, provides a therapeutic options, and documents the stage of the disease process. The duration of effect, however, is variable. ${ }^{35}$ Adjunctive therapies such as nonsteroidal anti-inflammatory drugs and

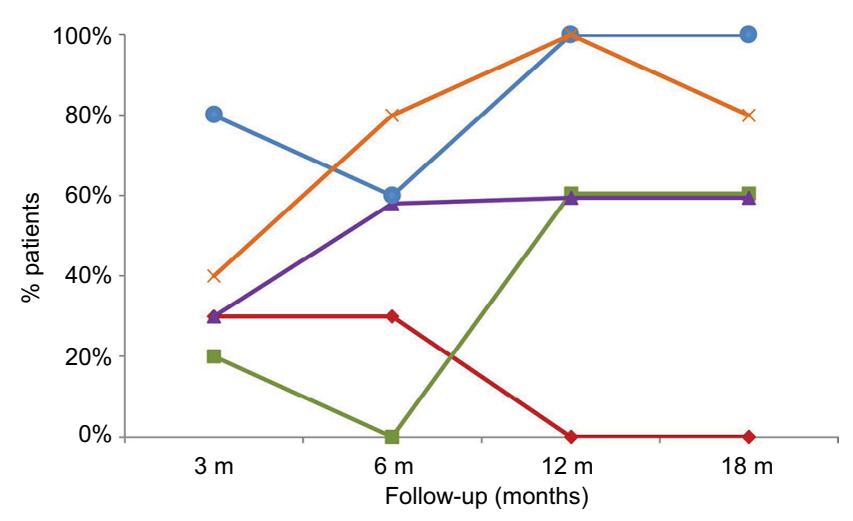

Figure 3 Percentage of patients with MCII (20\% relative change) in pain and function during the study by treatment group ( $\mathrm{n}=10$ patients/group). $\bullet \mathrm{HAI}$; $\mathrm{HA} 2$; X HA3; $\Delta$ PRP; Control p-values: 3 months: HAl vs HA2=0.007; 6 months: HA2 vs $\mathrm{HAI}=0.005$; vs $\mathrm{HA} 3<0.00 \mathrm{I}$; vs $\mathrm{PRP}=0.005$; 12 months: Control vs $\mathrm{HAI}=0.00 \mathrm{I}$; vs $\mathrm{HA} 2=0.005$; vs $\mathrm{HA} 3=0.00 \mathrm{I}$; vs $\mathrm{PRP}=00.005$; and 18 months: Control vs $\mathrm{HAI}=0.00 \mathrm{I}$; vs $\mathrm{HA} 2=0.005$; vs $\mathrm{HA} 3=0.00 \mathrm{I}$; vs $\mathrm{PRP}=0.005$.

Abbreviations: MCII, Minimally Clinical Important Improvement; PRP, platelet-rich plasma.

other medications, physiotherapy, and IA steroid injections may be incorporated to improve the results. ${ }^{36,37}$

The use of arthroscopic surgery in the treatment of OA has generated much discussion. Whereas some studies ${ }^{14,15}$ reported no differences with placebo arthroscopy, other studies confirm that, in patients with preoperative mechanical 
symptoms secondary to loose bodies, chondral flaps, and meniscal pathology, the use of arthroscopic surgery is beneficial. ${ }^{38,39}$ The key point is to offer knee arthroscopy to selected patients. Patients with symptomatic meniscal tears, few degenerative changes, normal axis, and acute mechanical complaints can benefit from this intervention, especially if the OA is mild or moderate. ${ }^{40-42}$ Favorable results have been also shown for the management of the infrapatellar fat pad impingement and Hoffa's disease. ${ }^{43,44}$ Chronic complaints, previous surgical intervention, degenerative changes in two or three compartments, significant axis deviation, ligament imbalance, or severe cartilage destruction are among the characteristics of patients who may be candidates for unsatisfactory results after arthroscopy. ${ }^{42}$

As a result, arthroscopic knee surgery is the most common type of orthopedic surgery performed in the developed world. ${ }^{45}$ However, in patients with symptomatic OA, pain can persist after arthroscopic meniscectomy and/or debridement of chondral lesions.

Treatment combining arthroscopic surgery and viscosupplementation has been widely used for patients with combined intraarticular mechanical and articular surface pathology. ${ }^{40}$ Initially, rheological characteristics that confer a lubricating effect to HA were considered the primary mechanism of action in treating OA pain. Nevertheless, rather than being a mere device, HA has been shown to exert other effects such as inhibition of tissue nociceptors, inhibition of matrix metalloproteinases, free radicals scavenging, and stimulation of endogenous HA production. Due to this, viscosupplementation has been recommended as adjunctive therapy after arthroscopic surgery as a suitable way of achieving long-term stabilization of the treatment outcome. ${ }^{40,44,46}$

The application of PRP to patients with OA was developed because of the physiological roles of several bioactive proteins and growth factors expressed in platelets, which lead to tissue regeneration. Despite the use of PRPs having been extended to the treatment of several musculoskeletal injuries the last few years, we have not found published studies analyzing the efficacy of PRP as adjunctive treatment in post-arthroscopy patients. A recent meta-analysis found that at 6 months post injection, PRP and HA had similar effects with respect to pain relief and functional impairment. However, at 12 months, PRP was associated with better improvement scores. ${ }^{47}$

In our study, the indication for knee arthroscopy was symptomatic rupture of a meniscus with symptomatic osteochondral detachment in patients with grade II OA. In these patients, surgery is the only and necessary indication, and they were given additional IA treatment with hyaluronate or
PRP due to the presence of OA. In the market, there are a variety of HAs and our aim has been to verify if the differences between HA products has any clinical relevance, as well as to study the effects of PRP after knee arthroscopic debridement. Procedures for clinical practice and the dosage described by the manufacturers have been used; according to the studies published, treatments with HA usually started 3 weeks after surgery. ${ }^{3,35,44,48,49}$ In absence of recommendations in the literature, PRP injection was administered immediately after arthroscopy.

The HA1 product showed the best results, with a very significant improvement of the symptomatology compared to the baseline that was maintained up to 18 months postarthroscopy (reduction of $-65.20 \%$ in total WOMAC) and with $100 \%$ of the patients reaching the MCII $20 \%$ in pain and function, followed by HA3 with a reduction of -49.57 in total WOMAC and $80 \%$ of patients reaching the $20 \%$ MCII cutoff. These products differ in origin, MW, structure, and number of injections administered and, in our study, the differences between both did not reach statistical significance. However, it should be noted that $8 / 10$ patients in the HA3 group were $\mathrm{KL}$ grade I, which is associated with better response data. ${ }^{40,41}$ The HA2 group showed much more discreet and erratic results, with final reduction in WOMAC at the end of the study and nearly $30 \%$ and $60 \%$ of patients complying with MCII requirements. It should be noted that, in this group, all patients had OA grade II as well as a greater number of overweight/obese patients - a characteristic that may also have influenced the results. ${ }^{44}$

A recent meta-analysis found that, at 6 months post injection, PRP and HA had similar effects with respect to pain relief and functional impairment. However, at 12 months, PRP was associated with better improvement scores. ${ }^{47}$ In our study, patients treated with PRP constitute a diverse group who seem to follow the rule of all or nothing, so that those who improve do so in a very significant way and this improvement is maintained until the end of followup, whereas something similar occurs with non-responder patients; thus, at the end of the study, only $60 \%$ of patients achieved the MCII threshold. Ayhan et $\mathrm{al}^{50}$ suggest that PRP therapy would be indicated for patients $<60$ years and with a $\mathrm{BMI}<30$. In our study, the best results in the PRP group were also seen in patients with a $\mathrm{BMI}<30$, as well as in those $<60$ years. We did not find any another relationship between the type of response and the characteristics of the patients or the arthroscopic findings.

Surprisingly, the control group showed low improvement in symptomatology at early follow-up that worsened along 
time with return to pre-arthroscopy levels at the 12-month follow-up that required the consumption of rescue medication.

One of the weaknesses of our study is the small sample size as it was designed as a pilot evaluation with the limitations that it entails when establishing comparisons; moreover, the fact that each group was evaluated by a different person may have influenced the evaluation of the results. Finally, not all patients undertook the rehabilitation protocol in the same way, as they were treated by different people and in different clinics according to the personal needs of the patient: a more strict control of this procedure would have been desirable. In our favor, the long follow-up period allowed us to assess the evolution of the results in the long term; the criteria used for patient selection was of special relevance to select those who may benefit most from the procedure, as was the presence of a control group. The design of the study also allowed us to study the behavior of three different HAs used within routine practice and to compare them with PRP as a new therapeutic approach.

Viscosupplementation is an effective treatment for the treatment of knee OA. Based on our results, we consider that its use in combination with arthroscopic surgery can provide very good results in adequately selected patients with an individualized and multidisciplinary follow-up. However, due to the importance of this type of intervention, further controlled studies with a larger sample size and/or alternative posology regimens would be of interest for the scientific community.

\section{Acknowledgments}

The authors thank Juan J. Granizo (Granadatos S.L.) for the statistical analysis of the results.

\section{Disclosure}

The authors report no conflicts of interest in this work.

\section{References}

1. Ornetti P, Nourissat G, Berenbaum F, Sellam J, Richette P, Chevalier $\mathrm{X}$; under the aegis of the Osteoarthritis Section of the French Society for Rheumatology (Société Française de Rhumatologie, SFR). Does platelet-rich plasma have a role in the treatment of osteoarthritis? Joint Bone Spine. 2016;83(1):31-36.

2. Loeser RF. Age-related changes in the musculoskeletal system and the development of osteoarthritis. Clin Geriatr Med. 2010;26(3):371-386.

3. Bruyère $\mathrm{O}$, Cooper $\mathrm{C}$, Pelletier $\mathrm{JP}$, et al. An algorithm recommendation for the management of knee osteoarthritis in Europe and internationally: a report from a task force of the European Society for Clinical and Economic Aspects of Osteoporosis and Osteoarthritis (ESCEO). Semin Arthritis Rheum. 2014;44(3):253-263.

4. Trueba Davalillo CÁ, Trueba Vasavilbaso C, Navarrete Álvarez JM, et al. Clinical efficacy of intra-articular injections in knee osteoarthritis: a prospective randomized study comparing hyaluronic acid and betamethasone. Open Access Rheumatol. 2015;7:9-18.
5. Yu CJ, Ko CJ, Hsieh CH, et al. Proteomic analysis of osteoarthritic chondrocytes reveals the hyaluronic acid-regulated proteins involved in chondroprotective effect under oxidative stress. J Proteomics. 2014;99:40-53.

6. Peng H, Zhou JL, Liu SQ, Hu QJ, Ming JH, Qiu B. Hyaluronic acid inhibits nitric oxide-induced apoptosis and dedifferentiation of articular chondrocytes in vitro. Inflamm Res. 2010;59(7):519-530.

7. Waddell DD, Kolomytkin OV, Dunn S, Marino AA. Hyaluronan suppresses IL-1beta-induced metalloproteinase activity from synovial tissue. Clin Orthop Relat Res. 2007;465:241-248.

8. Karna E, Miltyk W, Pałka JA, Jarzabek K, Wołczyński S. Hyaluronic acid counteracts interleukin-1-induced inhibition of collagen biosynthesis in cultured human chondrocytes. Pharmacol Res. 2006;54(4): 275-281.

9. Berenbaum F, Grifka J, Cazzaniga S, et al. A randomised, doubleblind, controlled trial comparing two intra-articular hyaluronic acid preparations differing by their molecular weight in symptomatic knee osteoarthritis. Ann Rheum Dis. 2012;71(9):1454-1460.

10. Foster TE, Puskas BL, Mandelbaum BR, Gerhardt MB, Rodeo SA. Platelet-rich plasma: from basic science to clinical applications. $\mathrm{Am} \mathrm{J}$ Sports Med. 2009;37(11):2259-2272.

11. McAlindon TE, Bannuru RR, Sullivan MC, et al. OARSI guidelines for the non-surgical management of knee osteoarthritis. Osteoarthritis Cartilage. 2014;22(3):363-388.

12. Spahn G, Klinger HM, Hofmann GO. How valid is the arthroscopic diagnosis of cartilage lesions? Results of an opinion survey among highly experienced arthroscopic surgeons. Arch Orthop Trauma Surg. 2009;129(8): 1117-1121.

13. Simpson DA, Thomas NP, Aichroth PM. Open and closed meniscectomy: a comparative analysis. J Bone Joint Surg Br. 1986;68: 301-304.

14. Kirkley A, Birmingham TB, Litchfield RB, et al. A randomized trial of arthroscopic surgery for osteoarthritis of the knee. $N$ Engl J Med. 2008;359(11):1097-1107.

15. Moseley JB, O'Malley K, Petersen NJ, et al. A controlled trial of arthroscopic surgery for osteoarthritis of the knee. N Engl J Med.2002; 347(2):81-88.

16. Herrlin S, Hallander M, Wange P, Weidenhielm L, Werner S. Arthroscopic of conservative treatment of degenerative medial meniscus tears: a prospective randomized trial. Knee Surg Sports Traumatol Arthosc. 2007;15(4):393-401.

17. Marx RG. Arthroscopic surgery for osteoarthritis of the knee? N Engl J Med. 2008;359(11):1169-1170.

18. Bhattacharyya T, Gale D, Dewire P, et al. The clinical importance of meniscal tears demonstrated by magnetic resonance imaging in osteoarthritis of the knee. J Bone Joint Surg Am. 2003;85-A(1):4-9.

19. Day B, The indications for arthroscopic debridement for osteoarthritis of the knee. Orthop Clin North Am. 2005;36(4):413-417.

20. Dye SF, Vaupel GL, Dye CC. Conscious neurosensory mapping of the internal structures of the human knee without intraarticular anesthesia. Am J Sports Med. 1998;26(6):773-777.

21. Durand A, Richards CL, Malouin F. Strength recovery and muscle activation of the knee extensor and flexor muscles after arthroscopic meniscectomy. A pilot study. Clin Orthop Relat Res. 1991;262: 210-226.

22. Huskin JP, Vandekerckhove B, Delincé P, et al. Multicentre, prospective, open study to evaluate the safety and efficacy of hylan G-F 20 in knee osteoarthritis subjects presenting with pain following arthroscopic meniscectomy. Knee Surg Sports Traumatol Arthrosc. 2008;16(8):747-752.

23. Bhadra AK, Altman R, Dasa V, et al. Appropriate use criteria for hyaluronic acid in the treatment of knee osteoarthritis in the United States. Cartilage. 2017;8(3):234-254.

24. De Rezende MU, de Campos GC. Viscosupplementation. Rev Bras Ortop. 2012;47(2):160-164.

25. Kaux JF, Le Goff C, Renouf J, et al. Comparison of the platelet concentrations obtained in platelet-rich plasma (PRP) between the GPS II and GPSTM III systems. Pathol Biol (Paris). 2011;59(5):275-277. 
26. Wichmann BA, Hill ID. Algorithm AS 183: an efficient and portable pseudo-random number generator. Appl Stat. 1982;31(2):188-190.

27. McLeod AI. Remark AS R58: a remark on algorithm AS 183. An efficient and portable pseudo-random number generator. Appl Stat. 1985;34(2): 198-200.

28. Mink JH, Levy T, Crues JV 3rd. Tears of the anterior cruciate ligament and menisci of the knee: MR imaging evaluation. Radiology. 1988;167(3):769-774.

29. Kellgren JH, Lawrence JS. Radiological assessment of osteoarthritis. Ann Rheum Dis. 1957;16(4):494-502.

30. Outerbridge RE. The etiology of chondromalacia patellae. J Bone Joint Surg Br. 1961;43:752-757.

31. Batlle-Gualda E, Esteve-Vives J, Piera Riera MC, Hargreaves R, Cutts J. Traducción y adaptación al español del cuestionario WOMAC específico para artrosis de rodilla y cadera [Translation and adaptation to Spanish of the WOMAC questionnaire specific for knee and hip osteoarthritis] Rev Esp Reumatol. 1999;26:38-45. Spanish [with English abstract].

32. Escobar A, Quintana JM, Bilbao A, Azkárate J, Güeaga JI. Validation of the Spanish version of the WOMAC questionnaire for patients with hip or knee osteoarthritis. Western Ontario and McMaster Universities Osteoarthritis Index. Clin Rheumatol. 2002;21(6):466-471.

33. Tubach F, Ravaud P, Baron G, et al. Evaluation of clinically relevant changes in patient reported outcomes in knee and hip osteoarthritis: the minimal clinically important improvement. Ann Rheum Dis. 2005;64(1): 29-33.

34. Tubach F, Ravaud P, Martin-Mola E, et al. Minimum clinically important improvement and patient acceptable symptom state in pain and function in rheumatoid arthritis, ankylosing spondylitis, chronic back pain, hand osteoarthritis, and hip and knee osteoarthritis: results from a prospective multinational study. Arthritis Care Res (Hoboken). 2012;64(11):1699-1707.

35. Heybeli N, Doral MN, Atay OA, Leblebicioğlu G, Uzümcügil A. Intraarticular sodium hyaluronate injections after arthroscopic debridement for osteoarthritis of the knee: a prospective, randomized, controlled study. Acta Orthop Traumatol Turc. 2008;42(4):221-227.

36. Van Oosterhout M, Sont JK, Bajema IM, Breedveld FC, van Laar JM. Comparison of efficacy of arthroscopic lavage plus administration of corticosteroids, arthroscopic lavage plus administration of placebo, and joint aspiration plus administration of corticosteroids in arthritis of the knee: a randomized controlled trial. Arthritis Rheum. 2006;55(6):964-970.
37. Smith MD, Wetherall M, Darby T, et al. A randomized placebocontrolled trial of arthroscopic lavage versus lavage plus intra-articular corticosteroids in the management of symptomatic osteoarthritis of the knee. Rheumatology (Oxford). 2003;42(12):1477-1485.

38. Matsusue Y, Thomson NL. Arthroscopic partial medial meniscectomy in patients over 40 years old: a 5- to 11-year follow-up study. Arthroscopy. 1996;12(1):39-44.

39. Bin SI, Lee SH, Kim CW, Kim TH, Lee DH. Results of arthroscopic medial meniscectomy in patients with grade IV osteoarthritis of the medial compartment. Arthroscopy. 2008;24(3):264-268.

40. Waddell DD, Bert JM. The use of hyaluronan after arthroscopic surgery of the knee. Arthroscopy. 2010;26(1):105-111.

41. Lamplot JD, Brophy RH. The role for arthroscopic partial meniscectomy in knees with degenerative changes: a systematic review. Bone Joint $J$. 2016;98-B(7):934-938.

42. Uluçay C, Altintaş F, Ugutmen E, Beksaç B. The use of arthroscopic debridement and viscosupplementation in knee osteoarthritis. Acta Orthop Traumatol Turc. 2007;41(5):337-420.

43. Dragoo JL, Johnson C, McConnell J. Evaluation and treatment of disorders of the infrapatellar fat pad. Sports Med. 2012;42(1):51-67.

44. Rooney A, Wahba AJ, Smith TO, Donell ST. The surgical treatment of anterior knee pain due to infrapatellar fat pad pathology: a systematic review. Orthop Traumatol Surg Res. 2015;101(4):469-475.

45. Carr AJ, Price AJ, Glyn-Jones S, Rees JL. Advances in arthroscopy-indications and therapeutic applications. Nat Rev Rheumatol. 2015;11(2):77-85.

46. Hempfling $\mathrm{H}$. Intra-articular hyaluronic acid after knee arthroscopy: a two-year study. Knee Surg Sports Traumatol Arthrosc. 2007;15(5): 537-546.

47. Dai WL, Zhou AG, Zhang H, Zhang J. Efficacy of platelet-rich plasma in the treatment of knee osteoarthritis: a meta-analysis of randomized controlled trials. Arthroscopy. 2017;33(3):659-670.

48. Atay T, Aslan A, Baydar ML, Ceylan B, Baykal B, Kirdemir V. The efficacy of low- and high-molecular-weight hyaluronic acid applications after arthroscopic debridement in patients with osteoarthritis of the knee Acta Orthop Traumatol Turc. 2008; 42(4):228-233. [Article in Turkish]

49. Westrich G, Schaefer S, Walcott-Sapp S, Lyman S. Randomized prospective evaluation of adjuvant hyaluronic acid therapy administered after knee arthroscopy. Am J Orthop (Belle Mead NJ). 2009;38(12):612-616.

50. Ayhan E, Kesmezacar H, Akgun I. Intraarticular injections (corticosteroid, hyaluronic acid, platelet rich plasma) for the knee osteoarthritis World J Orthop. 2014;5(3):351-361.
Open Access Rheumatology: Research and Reviews

\section{Publish your work in this journal}

Open Access Rheumatology: Research and Reviews is an international, peerreviewed, open access journal publishing original research, reports, editorials, reviews and commentaries on all aspects of clinical and experimental rheumatology in the clinic and laboratory including the following topics: Pathology, pathophysiology of rheumatological diseases; Investigation, treatment and management of rheumatological diseases; Clinical trials and novel pharmacologi$\mathrm{cal}$ approaches for the treatment of rheumatological disorders. The manuscript management system is completely online and includes a very quick and fair peer-review system, which is all easy to use. Visit http://www.dovepress.com/ testimonials.php to read real quotes from published authors. 